\title{
The Effect of Ficol on $\alpha$-lactalbumin Aggregation
}

\author{
Seyed Hosseini B*, Ghahghaie A
}

\begin{abstract}
During folding pathway surface of amino acids are available which result to abnormal interaction between protein and environment and cause to aggregation. The intra cellular aggregation forms amyloid fibrils which has been seen in Alzheimer disease, type 2 Diabte. Amyloid aggregation is produced from deposition of intermediately folded protein states. In this study we evaluated the effect of molecular crowding agent,ficol, on $\alpha$-lactalbumin amyloid using light scattering spectroscopy, Tht binding assay, intrinsic fluorescence intensity, ANS binding assay and $\mathrm{CD}$ spectroscopy. Our results showed ficol ficol70 decreased the rate of aggregation and increased the lag phase of the reaction. The decrease of $\alpha$-lactalbumin amyloid aggregation is because of reduction in non specific interaction between ficol and $\alpha$ -lactalbumin and environment in the presence of ficol.
\end{abstract}

Keywords---Crowding agents, Amyloid aggregation, a -Lactalbumin

\section{INTRODUCTION}

$\mathrm{I}_{\mathrm{N}}^{\mathrm{N}}$ $\mathrm{N}$ vitro protein folding process was used widely as an efficient tool for finding the folding process in the cell.

After protein synthesis, new synthesized poly peptide is unfold, so in the protein folding pathway, protein fold to its normal and active form. During folding pathway surface of amino acids are available which result to abnormal interaction between protein and environment and cause to aggregation [1]. aggregations are insoluble which produce from unfold or semi-fold polypeptide and hold together by hydrophobic interaction. Aggregation is an inefficient end and abnormal in protein folding [2]. Common feature in most protein aggregation disorders during amyloid formation is disappearing alpha helix domain and producing beta sheet structure [3].

The bovine $\alpha$-lactalbumin (14KDa) is a globular calcium methalo protein which is stable with 4 disulfide bounds and also doesn't have a free thiol so it consider as thermal stable protein [4]. because $\alpha$ - lactalbumin form classic molten globule in acidic $\mathrm{pH}$, high tempreture conditions and apo HLA structure, so it make $\alpha$ - lactalbumin a proper model for molten globule studies [4], [5].

The phenomenon of macromolecular crowding is used for living systems describe that the total concentration of macromolecule is high enough to occupy amount of volume cell that is not accessible for other molecules. one of the crowded result is decrease in molecular diffusion rate and this effect happen in all small and big molecules, also crowded

Bahare Seyedhosseini (MSc) (*corresponding author) is with the Department of Biology, Faculty of Basic Sciences, University of Sistan and Baluchestan, Zahedan, Iran. (e-mail: bahare.seyedhosseini@yahoo.com).

Arezou Ghahghaei is with the Department of Department of Biology, Faculty of Basic Sciences, University of Sistan and Baluchestan, Zahedan, Iran. (Email: Arezou@chem.usb.ac.ir). effect are complex in biochemical interaction, because albeit it decrease the diffusion of molecules, it make an increase in thermodynamic interaction [6], [7].

Obviously, the volume that occupied by a molecules is not available to other molecule since two molecule cannot be in the same place at the same time, and thermodynamically the result of this effect are affecting macromolecular equilibria such as protein- protein interaction and significant alteration in the rate of the other chemical reaction, folding protein and interaction between macromolecules [8], [9].

we used crowded to mimic the cell environment to investigate the effect of crowding on interaction between chaperon and the protein. Also we choose this subject because the study of three macromolecular crowding agents together on beta- casein was not done before. The aim of this study was to investigate the effect of macromolecular crowding agent ficol on the amyloid formation and amorphous aggregation of $\alpha$-lactalbumin.

\section{MAterial AND MethodS}

Bovin $\alpha$-lactalbumin $\quad(14 \mathrm{kDa}), \quad \beta$-casein $\quad(24 \mathrm{kDa})$, dextran70, ficol70, polyethylene glycol, 1,4- dithiotherithol (DTT), $\mathrm{NaN}_{3}, \mathrm{Na}_{2} \mathrm{HpO}_{4}$, thioflavin $\mathrm{T}$ (Tht), 1-anilino-8naphthalene sulfonic acid (ANS), all obtained from sigmaAldrich.

Fibril formation of $\alpha$-lactalbumin $(2 / 5 \mathrm{mg} / \mathrm{ml})$ was investigate in presence and absence of dextran, ficol and PEG $(10 \% \mathrm{w} / \mathrm{v}), \beta$-casein ( $1: 1$ molar ratio). All sampe incubated in $50 \mathrm{mM}$ sodium phosphate, $\mathrm{pH}: 7 / 4$ in an incubator(A-Q, Germany) at $37^{\circ}$. DTT was added to a final concentration of $20 \mathrm{mM}$ to commence the unfolding and aggregation of $\alpha$ -lactalbumin. Samples were shaken at $210 \mathrm{rpm}$ to accelerate amyloid fibril formation. To deliberate fibril formation and the effect of crowding agents on $\beta$-casein activity, Tht was added to the samples and amyloid formation was measured by Tht fluorescence on Varian spectrofluorimetre. The wave length of excitation and emission was respectively $446 \mathrm{~nm}$ and 450-600nm with $5 \mathrm{~nm}-5 \mathrm{~nm}$ slit width .

The intrinsic fluorescence intensity of $\alpha$-lactalbumin $(10$ $\mu \mathrm{M}$ ), and $20 \mathrm{mM}$ DTT in $50 \mathrm{mM}$ sodium phosphate, $0 / 1 \%$ $\mathrm{NaN}_{3}$ and $\mathrm{pH} 7 / 4$ in presence and absence of ficol was studied after 3 hours incubation at $37^{\circ}$. Fluorescence intensity were obtained on a Varian Eclips fluorescence spectrofluorimetre equipped with tempreture control. The excitation and emission wave length of tryptophan residue were $295 \mathrm{~nm}$ and $300-400 \mathrm{~nm}$ with $2 / 5 \mathrm{~nm}$ and $5 \mathrm{~nm}$ slit width, respectively.

\section{RESULTS}

Reduced $\alpha$-lactalbumin at natural $\mathrm{pH}$ 7-7.4 adopts a molten globule conformation which make it prone to amyloid fibril formation [10]. 
In order to investigate the effect of macromolecular crowding, ficol, on the aggregation of $\alpha$-lactalbumin. ThT binding assay showed that the fluorescence intensity of ThT of reduced $\alpha$-lactalbumin increased at pH 7.4 (11). The ThT intensity of $\alpha$-lactalbumin decreased in presence of ficol which means ficol could suppress amyloid formation of a-lactalbumin.

According to table 1, the rate constant of amyloid formation of $\alpha$-lactalbumin was $0.596 \pm 0.02$ while in presence of ficol it decrease to $0.49 \pm 0.02$.

TABLE I

RATE CONCENTRATION Of AMYLOID FoRMATION FOR A-LACTALbUMIN IN ThioflaVin T-Binding ASSAY IN PRESENCE AND ABSENCE OF FiCOL (10\% $\mathrm{W} / \mathrm{V})$.

\begin{tabular}{|l|l|}
\hline Sample components & $\begin{array}{c}\text { Rate constant } \times 10^{-1} \\
\left(\mathrm{~min}^{-1}\right)\end{array}$ \\
\hline $\boldsymbol{\alpha}$-lactalbumin & $0.596 \pm 0.02$ \\
\hline $\begin{array}{l}\boldsymbol{\alpha} \text {-lactalbumin+ } \\
\text { Ficol }\end{array}$ & $0.49 \pm 0.02$ \\
\hline
\end{tabular}

\section{Fluorescence spectroscopy:}

\section{Intrinsic fluorescence}

Intrinsic fluorescence intensity assay was used to show the effect of ficol on structural changes of $\alpha$-lactalbumin. The intrinsic fluorescence of tryptophan show enviroment changes of Trp residue during the folding/unfolding process [12]. According to figure I, adding ficol to $\alpha$-lactalbumin showed an increased in the fluorescence intensity, So the intrinsic fluorescence of $\alpha$-lactalbumin in the presence of ficol was about $70 \%$ less compare with sum of individual proteins.

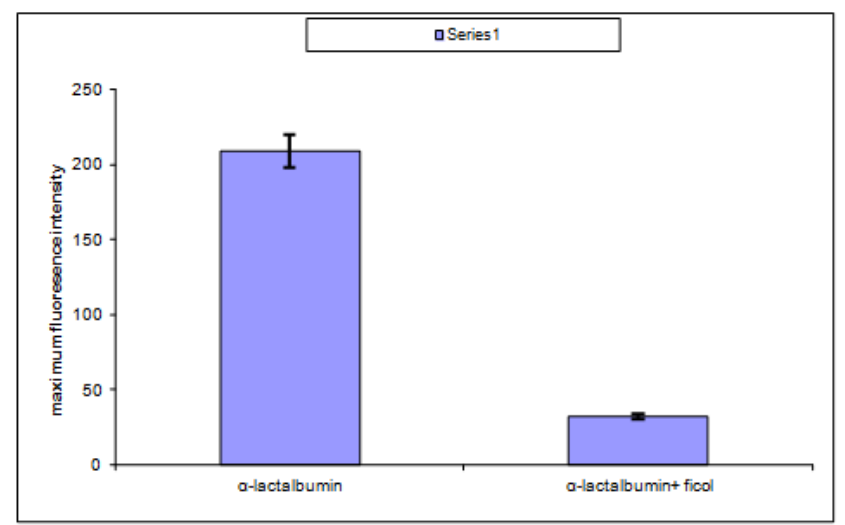

Fig I. The maximum fluorescence intensity of $\alpha$-lactalbumin (10 $\mu \mathrm{M})$ in presence and absence of ficol $(10 \% \mathrm{w} / \mathrm{v})$. All samples were incubated 3 hours in $50 \mathrm{mM}$ phosphate buffer, $0.005 \% \mathrm{NaN}_{3}$, $\mathrm{pH} 7.4$ and at $37^{\circ} \mathrm{C}$.

\section{DISCUSSION}

The intra cellular environment is full of crowded because of the high concentration of soluble and insoluble macro molecule, so a large amount of intra cellular space isn't accessible to other molecules while these circumstance does not exist in in vitro environment. So the crowding theory suggests that the crowded of the cell can have effect on thermodynamic action of every molecule in the cell [13], [14]. The aim of this study was to find out the effect of macromolecular crowding agent, ficol, on structural changes and amyloid formation of $\alpha$-lactalbumin.

Ficol70 is one of suitable model to create a cellular crowded enviroment, where the folding process done.
The thioflavin $\mathrm{T}$ binding assay showed that ficol decreased the rate of amyloid aggregation of $\alpha$-lactalbumin and increase the lag phase of amyloid formation.

To investigated these results we used intrinsic fluorescence intensity in the presence of ficol. The intrinsic experiment showed that the fluorescence intensity had a remarkable decrease in the presence of ficol.

Some study show non-specific interactions, could lead to unstable protein formation, also small proteins unstable the proteins and big protein stable proteins [15],[16]. This study show there wasn't non- specific interaction between ficol and $\alpha$-lactalbumin. also Physiological heterogeneous crowding environment can lead to an environment which protein can be stable or unstable by total volume occupied and total non-specific interaction [1], [2].

\section{CONCLUSION}

We have shown that ficol as a crowding agent can affect the polarity changes around amino acids of $\alpha$-lactalbumin. Also ficol could decrease the rate of amyloid formation, so it can be conclude that ficol can have positive effect on prevent the amyloid aggregation o $\alpha$-lactalbumin.

\section{ACKNOWLEDGMENT}

We appreciate all who helped us to exert the present study.

\section{REFERENCES}

[1] Miklos AC, Li C, Sharaf NG and Pielak GJ. Volume exclusion and soft Interaction effects on protein stability under crowded conditions. Biochemistry, 49: 6984 -6991, 2010 . http://dx.doi.org/10.1021/bi100727y

[2] Schlesinger AP, Wang Y, Tadeo X, Millet O and Pielak GJ. Macromolecular crowding fails to fold a globular protein in cells. J Am Chem Soc, 133: 8082-8085, 2011. http://dx.doi.org/10.1021/ja201206t

[3] Yong-Qiang Fan, Hong-Jian Liu. Effects of macromolecular crowding on refolding of recombinant human brain-type creatine kinase. International Journal of Biological Macromolecules 51 ,113- 118, 2012. http://dx.doi.org/10.1016/j.ijbiomac.2012.04.014

[4] Dolgikh, D.A., Gilmanshin, R.I., Brazhnikov, E.V., Bychkova, V.E., Semisotnov, G.V., Venyaminov, S.Y. Ptitsyn, O.B., $\alpha$-Lactalbumin: Compact State with Fluctuating Tertiary Structure, FEBS Lett, Vol. 136, pp. 311-315, 1981. http://dx.doi.org/10.1016/0014-5793(81)80642-4

[5] Kuwajima, K., The molten globule state of $\alpha$-lactalbumin., FASEB J, Vol. 10, pp. 102-109, 1996.

[6] Steven B. Zimmerman, Allen P. Minton, MACROMOLECULAR CROWDING: Biochemical, Biophysical, and Physiological Consequences. Annu. Rev. Biophys. Biomol. Struct. 1993. http://dx.doi.org/10.1146/annurev.bb.22.060193.000331

[7] R John Ellis, Macromolecular crowding: an important but neglected aspect of the intracellular environment., Current Opinion in Structural Biology2001, 11:114-119. Elsevier Science Ltd, 2001.

[8] Larissa A. Munishkina, Atta Ahmad Anthony L. Fink, and Vladimir N. Uversky., Guiding protein aggregation with macromolecular crowding. Biochemistry. Author manuscript; available in PMC Aug 26, 2009.

[9] Ellis RJ. Macromolecular crowding: obvious but underappreciated Trends Biochem Sci. 2001;26:597-604. http://dx.doi.org/10.1016/S0968-0004(01)01938-7

[10] Goers, J., Permyakov, S. E., Uversky, V. N., \& Fink, L. A (2002).Biochemistry, 41,12546-12551. http://dx.doi.org/10.1021/bi0262698

[11] Arezou Ghahghaei \& Somaye Mohammadian, The Effect of Arg on the Structure Perturbation and Chaperone Activity of $\alpha$-Crystallin in the Presence of the Crowding Agent, Dextran, Appl Biochem Biotechnol (2014) 174:739-750 http://dx.doi.org/10.1007/s12010-014-1092-y

[12] Swaisgood, H. E. (1992).Advanced dairy chemistry-1: protein(2nd ed., pp. 63-110). London: Elsevier Applied Science. 
[13] Steven B. Zimmerm, Allen P. Minto, MACROMOLECULAR CROWDING: Biochemical, Biophysical, and Physiological Consequences. Annu. Rev. Biophys. Biomol. Struct. 1993 http://dx.doi.org/10.1146/annurev.bb.22.060193.000331

[14] Bert Van Den Berg et all., Mocromolecular Crowding perturbs protein refolding kinetic: implication for folding inside the cell., The EMBO Journal. Vol. 10. Number 15 pp.3870-3875, 2000.

[15] De-Lin Zhang, Ling-Jia Wu, Jie Chen, and Yi Liang(2012)., Effects of macromolecular crowding on the structural stability of humana-lactalbumin. Acta Biochim Biophys Sin, 44: 703-711, 2012. http://dx.doi.org/10.1093/abbs/gms052

[16] Zhou Y and Hall CK. Solute excluded-volume effects on the stability of globular proteins: A statistical thermodynamic theory. Biopolymers, 38: $273-284,1996$.

http://dx.doi.org/10.1002/(SICI)1097-0282(199602)38:2<273::AID-

BIP11>3.3.CO;2-7 